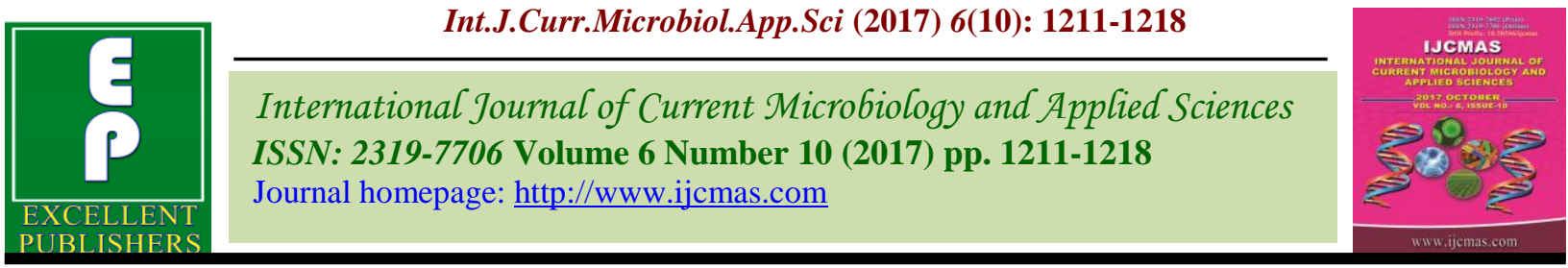

Review Article

https://doi.org/10.20546/ijcmas.2017.610.146

\title{
Soil Enzyme Activity as Affected by Tillage and Residue Management Practices under Diverse Cropping Systems
}

\author{
Rituparna Saikia* and Sandeep Sharma \\ Department of Soil Science, Assam Agricultural University, Jorhat, Assam, India \\ *Corresponding author
}

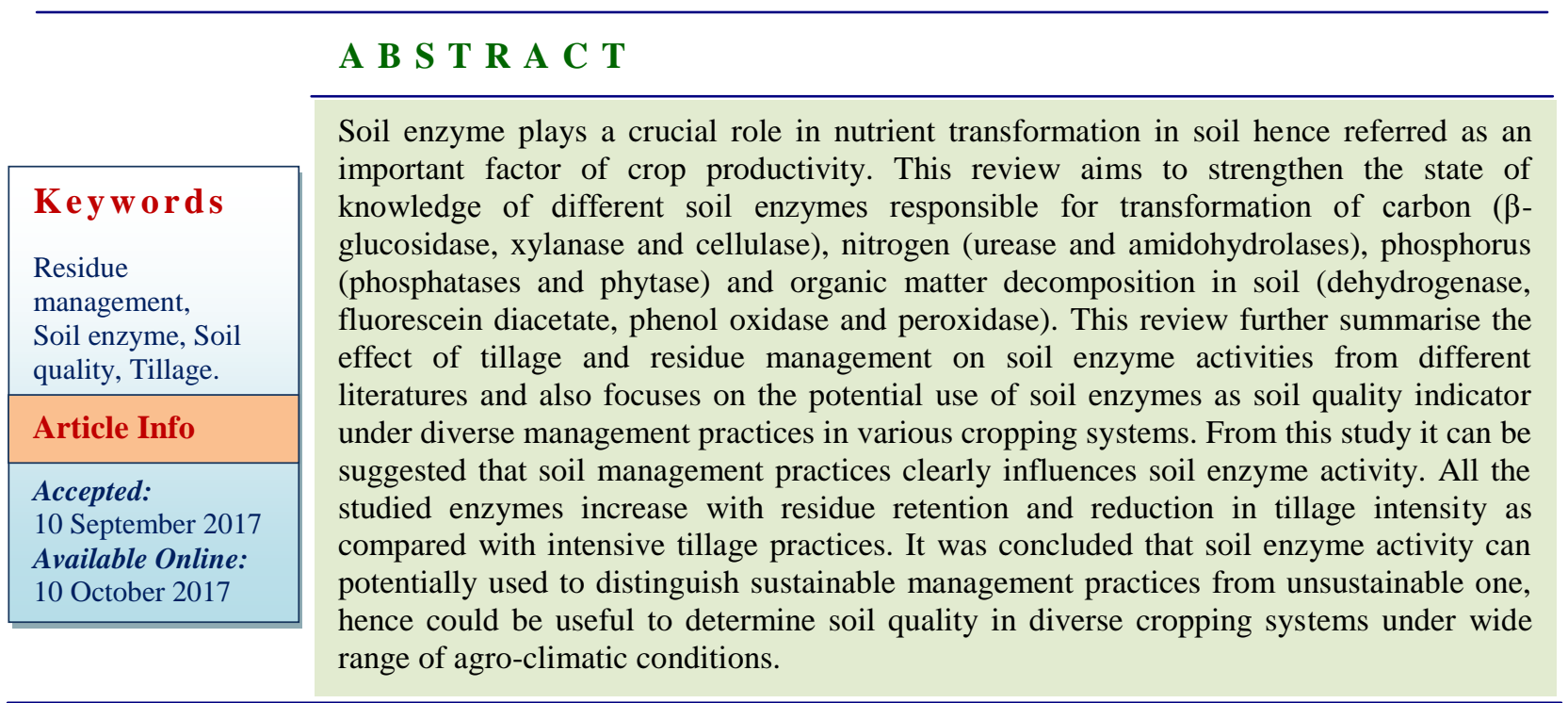

\section{Introduction}

Soil management practices influences population of microorganisms and soil microbial processes through changes in the quantity and quality of plant residues in the soil profile (Kandeler et al., 1999). Soil enzymes are indispensible for nutrient cycling in ecosystems and biotic and abiotic factors including quantity and quality of litter input, moisture and temperature are determining factor for their activity. The hydrolytic enzymes are involved in the dynamics of soil nutrient transformations and their activity in soil is considered to be a major contributor of overall soil microbial activity (Frankenberger and Dick, 1983) and soil quality (Visser and
Parkinson, 1992). Modification of microbial dynamics on account of management practices may also be reflected in differences in enzyme activities in soils. Soil physical, chemical, biological and biochemical properties can be significantly altered by tillage and residue management practices, which in turn lead to alteration of the composition, distribution and activities of soil microbial community and enzymes (Dick, 1984; Magnan and Lynch, 1986). Accumulation of organic matter and nutrients at the surface soil layer under reduced tillage produces beneficial effects on soil physical, chemical and biological properties (Beare et 
al., 1997). These improvements are generally associated with enhanced rhizosphere biological activities (Kladivko, 2001). Notillage (NT) has been shown to increase microbial biomass (Helgason et al., 2010), improve soil carbon (Lal et al., 2003), increase mineralizable $\mathrm{N}$ (Spargo et al., 2011), soil moisture (Ma et al., 2008) and enzyme activities (Alvear et al., 2005). Soil enzyme activities are accepted as early and more reliable bio indicators than soil physicochemical properties under different tillage systems. Dick et al., (1988) and Nannipieri (1994) recommend the measurement of enzymatic activity as both an early and sensitive indicator of management-induced changes in soil quality. This paper intend to summarise studies pertaining to different soil enzymes as affected by tillage and residue management practices and also depicts its potential to be used as sensitive indicator of soil quality in different cropping system in different agro-climatic conditions. This is an approach to seriously contemplating to realise the importance of this hitherto unexplored sector.

\section{Dehydrogenase and fluorescein diacetate activity}

Dehydrogenase activity (DHA) is reported to be a sensitive indicator of overall soil biological and microbial activity (Quilchano and Maranon, 2002) because it is associated with oxidation-reduction processes in living cell (Alef and Nanniperi, 1995). DHA represents the total range of oxidative activity of soil microflora and therefore acts as a good indicator of microbiological activity (Nannipieri et al., 1990). DHA has been reported to be an efficient indicator of soil quality in rice-wheat-jute and other cropping systems (Chaudhury et al., 2005). Fluorescein diacetate activity (FDA) is reported to be an indirect appraisal of metabolic activity of microbial population in soils. The FDA represents the hydrolytic activity of soil microorganisms and quantify overall microbial activity (Adam and Duncan, 2001; Dutta et al., 2010). The hydrolysis of fluorescein diacetate has the latent ability to broadly depict soil enzyme activities (Schnurer and Rosswall, 1982) and accumulated biological effects since FDA is hydrolyzed by a number of diverse groups of enzymes such as protease, lipase and esterases (Rotman and Paperaster, 1966) which are associated with the microbial decomposition of organic matter in soil. Parihar et al., (2016) carried out a long term field experiment comprising different tillage permutations (permanent raised bed, zero tillage and conventional tillage) and intensive maizebased cropping systems (Maize-wheatMungbean, Maize-Chickpea-Sesbanea, Maize-Musturd-Mungbean, Maize-MaizeSesbanea). They observed that DHA and FDA were significantly higher under zero tillage and permanent bed than conventional tillage (CT). They further observed higher DHA and FDA under Maize-ChickpeaSesbanea cropping system as compared with other systems. Majchrzak et al., (2016) observed significant impact of tillage systems on DHA in a wheat crop. It showed significantly higher activity under NT at all the growth stages of wheat. Bhaduri et al., (2017) observed that DHA after harvesting of wheat crop was $11 \%$ higher under previously non puddled soil as compared with puddled soil in a long term rice-wheat system in IndoGangatic plain in India. Kumawat et al., (2017) reported significant increase of FDA in $0-5 \mathrm{~cm}$ soil layer in a maize-wheat system with $50 \%$ and $75 \%$ residue retention of each crop. Kumar et al., (2017) reported significant increase of FDA under reduced tillage practices $\left(30.8 \mu \mathrm{g} \mathrm{ha}^{-1}\right)$, followed by no tillage $\left(27.9 \mu \mathrm{g} \mathrm{ha}^{-1}\right)$ as compared with conventional tillage practices $\left(22.9 \mu \mathrm{g} \mathrm{ha}^{-1}\right)$ in $0-15 \mathrm{~cm}$ soil layer. Neogi et al., (2014) reported 15.4\% increase in FDA under minimum tillage as 
compared with conventional tillage in a ricemaize-cowpea cropping system.

\section{Phosphatases and phytase activity}

Acid and alkaline phosphatases are associated with release of inorganic phosphate from organic matter, and are known to perform important role in phosphorus cycle in soil ecosystems (Speir and Ross, 1975). These extracellular enzymes act as an important link between biologically unavailable and mineral phosphorus as they catalyze the hydrolysis of organic phosphate esters to orthophosphate. Alteration of soil environment by tillage, water logging, compaction and fertilization significantly affect phosphatase activity in soil. Acid and alkaline phosphatases have different substrate specificity and $\mathrm{pH}$ optimum (Balota et al., 2003; Canarutto et al., 1995). These enzymes originate either from plant roots (and associated mycorrhiza or other fungi) or from bacteria (Tarafder and Marschner, 1994). Alkaline phosphatases are mainly produced by bacteria, fungi and earthworm (Hebrien and Neal, 1990). These enzymes are frequently referred as ectoenzymes i.e. enzymes acting outside but still linked to cells of their origin. Acosta-martinez et al., (2003) observed significant increase in alkaline phosphatase activity under conservation tillage as compared with conventional tillage practices in semi-arid agricultural soil under cotton based cropping systems. Gajda et al., (2013) reported 18-30\% higher alkaline phosphatase activity in a wheat crop under reduced tillage (RT) as compared with conventionally tilled wheat. Singh and Ghosal (2013) concluded that application of FYM and wheat straw along with inorganic fertilizer significantly increased the activity of alkaline phosphatase in $0-10 \mathrm{~cm}$ soil layer as compared with the application of inorganic fertilizer alone in a double no-till rice-wheat system. Mathew et al., (2012) reported that acid and alkaline phosphatase activity was higher under NT than CT soil at $0-5 \mathrm{~cm}$ soil depth in a longterm tillage experiment in continuous corn system in a silt loam soil.

Phytase (myo-inositol hexakisphosphate phosphohydrolases) catalyses the hydrolysis of inositol phosphates and are potentially important in the soil for their role in phosphorus mineralization due to conversion of organic-P from phytate to plant available form (Ariza et al., 2013). The stability and activity of phytases in soil is affected by sorption on soil particle surfaces which may reduce the potential for interaction with substrates. However this may also provide long-term advantages for their persistence and function in soil (Nannipieri et al., 1996). Yadav and Tarafdar (2004) observed that NT practices substantially increases phytase activity in soil. They concluded that roots of the weeds decomposed and contributed to increase in organic matter and microbial build up thereby increased phytase activity in soil.

\section{Urease and amidohydrolases activity}

Urease is a microbial enzyme, which hydrolyses the C-N peptide bonds of linear amides of urea and urea type $\mathrm{N}$ substrates, producing carbon dioxide and ammonia (Tabatabai, 1982). Urease is released from living and disintegrated microbial cells and acts as extracellular enzymes adsorbed on clay particles or encapsulated in humic complexes (Nannipieri et al., 1994). Raiesi and Kabiri (2016) reported higher urease activity in a barley crop under reduced tillage practices comprising of chisel and disk plough as compared with CT practices comprising of rotary and mouldboard plough in a 6 year study in semi-arid calcareous soil in central Iran. Evazi et al., (2003) reported that soil enzymatic activities (acid and alkaline phosphatases, alpha-glucosidase, arylsulfatase and urease) were higher in 
continuous corn under no tillage than conventionally tilled soil. Zhang et al., (2016) observed that activity of the enzymes (urease and sucrase) increased with the amount of straw applied. Incorporation of maize straw was more effective to increase enzyme activities as compared with wheat straw incorporation because of narrow $\mathrm{C}$ : $\mathrm{N}$ ratio of maize straw than wheat straw which facilitates faster decomposition of maize straw.

Amidohydrolases are enzymes associated with the hydrolysis of organic $\mathrm{N}$ compounds in soils. These enzymes are extensively distributed in nature and have been found in plants, animals and microorganisms (Tabatabai, 1994). One of the most important enzyme belong to this group is Lasparaginase, which catalyzes hydrolysis of L-asparagine to L-aspartic acid and ammonia. Hamido and Kpomplekou (2009) observed that no tilled plot preceded by leguminous crimson clover (Trifolium incarnatum L.) exhibited higher activity of L-asparaginase enzymes as compared with the plots preceded by black oat (Avena strigosa L.) or mixture of crimson clover and black oat. Ekenler and Tabatabai (2004) investigated the dynamics of arylamidase, L-asparaginase, L-glutaminase, amidase, urease and L-aspartase activity under three different tillage systems (no till, ridge till and chisel plough). They observed higher activity of all the enzymes under no till systems.

$\beta$-Glucosidase, xylanase and cellulase activity

$\beta$-glucosidase catalyzes the hydrolysis of $\beta$ glucosides in soil (Hayano and Tubaki, 1985) and such hydrolysis is of fundamental importance for microorganisms to obtain energy from soil (Evazi and Zakaria, 1993). The enzyme $\beta$-glucosidase acts in the final stage of decomposition of cellulose by hydrolysing the cellubiose residue to simple sugars (Passos et al., 2008), which are an important energy source for microbes (Waldrop et al., 2000). $\beta$-glucosidase enzyme is sensitive to any change in the management practices in soil and directly related to the amount of organic matter and considered as a promising soil quality indicator for assessing the changes induced by tillage practices (Ekenler and Tabatabai, 2003). De la Horra et al., (2003) observed that NT exhibited significantly higher activity of $\beta$-glucosidase enzyme at the surface $(0-5 \mathrm{~cm})$ soil layer as compared with CT. Roldan et al., (2003) concluded that NT with moderate amount of crop residue (33\%) and legume cover has significantly improved soil enzyme activities (DHA, urease, protease, $\beta$-glucosidase and acid phosphatase).

Xylanase (endo-1, 4- $\beta$-xylanase) enzymes are mainly responsible for decomposition of the polysaccharides of xylose. Xylanases are directly associated with decomposition of the hemicelluloses (Sinsabaugh et al., 1994) into short chain glycosides (Wong et al., 1988). Kandeler and Bohm (1996) observed higher xylanase activity at $0-10 \mathrm{~cm}$ soil layer under minimum tilled soil as compared with conventionally tilled soil in a fine sandy Haplic chernozem soil. Conversely, an opposite trend was observed at $20-30 \mathrm{~cm}$ soil layer; in this soil layer xylanase activity was significantly higher under conventional tillage as compared with minimum tilled soil.

Cellulases are a group of enzymes that catalyze the breakdown of cellulose, a polysaccharide formed of $\beta-1,4$ linked glucose units. Hence, cellulases perform a crucial role at the initial phase of decomposition of organic matter in soil. Li et al., (2016) investigated the effect of different combinations of mineral fertiliser and rice straw nitrogen on cellulase activity at different wheat growth stages. They observed 
that cellulase activity increases with application of rice straw as compared with application of mineral fertilizer and control (no fertilizer or straw). Cellulase activity was maximum under treatment with $30 \%$ rice straw $\mathrm{N}$ plus $70 \%$ fertilizer N. Bini et al., (2014) reported that cellulase activity under no tillage was lower as compared with conventional tillage. In contrary with the above results, Meena et al., (2008) reported that cellulase activity under conventional tillage system was 31.3-74.6\% higher than ZT practices in lentil-finger millet cropping system in a sandy clay loam soil in Himalayan sub-temperate region. Deng and Tabatabai (1996) reported that cellulase activity was higher under no till/double mulch as compared with chisel and mouldboard plough without mulching. Balota et al., (2003) recorded 68\%, 90\%, 219\%, 46\% and $61 \%$ increase of amylase, cellulase, arylsulfatase, acid phosphatase and alkaline phosphatase activity under NT as compared with CT in wheat based cropping systems in a subtropical ecosystem in Brazil.

\section{Phenol oxidase and peroxidase activity}

Phenol oxidase enzyme removes phenolic hydrogen to form radicals or quinines, hence catalyzes polyphenol oxidation in the presence of oxygen $\left(\mathrm{O}_{2}\right)$. These products go through nucleophilic addition reactions in the presence or absence of free- $\mathrm{NH}_{2}$ groups with the eventual production of humic acid-like polymers (Martin and Haider 1980; Stevenson 1994). The occurrence of phenol oxidase in soil environments is essential for the formation of humic substances. Peroxidases are enzymes associated with depolymerising lignin and use $\mathrm{H}_{2} \mathrm{O}_{2}$ as electron acceptor. Matocha et al., (2004) observed that after 33 year of imposed tillage and $\mathrm{N}$ fertilization treatments, activity of phenol oxidase under NT soil was 1.7 times higher than soil tilled with mouldboard plough in a corn/rye system. Benitez et al., (2006) reported lower phenol oxidase activity under NT as compared with conventional tillage in an olive orchard in Spain. Chu et al., (2016) analysed the effect of long term tillage and crop rotation practices on soil enzyme activities and observed significantly higher activity of phenol oxidase, dehydrogenase and $\beta$ glucosaminidase in the no tilled plot as compared with conventionally tilled plot. But the activity of peroxidase enzyme was significantly higher under CT plot than NT plot. Zhao et al., (2016) evaluated the effect of long term (30 years) maize straw incorporation at the rate of $0,2.25$ and $4.50 \mathrm{t}$ $\mathrm{ha}^{-1}$ on phenol oxidase activity in a wheatmaize cropping system. They observed that incorporation of maize straw at the rate of 2.25 and $4.5 \mathrm{t} \mathrm{ha}^{-1}$ decreased the activity phenol oxidase as compared with control. Mangalassery et al., (2015) observed that the activities of dehydrogenase, cellulase, xylanase, $\beta$-glucosidase, phenol oxidase and peroxidase were higher in zero tillage as compared with CT after 7 years in wheat and oilseed rape crop.

Tillage and residue management practices significantly alter enzyme activity in soil in diverse cropping systems. Reduction in the intensity of tillage and residue incorporation can substantially increase enzyme activity in soil which is an indication of better soil quality and sustainability of any cropping system. Soil enzymes can be a useful tool to determine sustainability of a system under various management practices.

\section{References}

Acosta-Martinez, V., Zobeck, T. M., Gill, T. E and Kennedy, A. C. 2003. Enzyme activities and microbial community structure in semiarid agricultural soils. Biol. Fertil. Soils 38: 216-227.

Adam, G., and Duncan, H. 2001. Development of a sensitive and rapid method for the measurement of total microbial activity using fluorescein diacetate (FDA) in a range of soils. Soil Biol. Biochem. 33: 943-951. 
Alef, K., and Nannipieri, P. 1995. Methods in applied soil microbiology and biochemistry. Academic Press, San Diego, USA.

Alvear, M., Rosas, A., Rouanet, J. L and Borie, F. 2005. Effect of three soil tillage systems on some biological activities in an Ultisol from southern Chile. Soil Till. Res. 82: 195-202.

Ariza, A., Moroz, O, V., Blagova, E. V., Turkenburg, J. P., Waterman, J., Roberts, S. M., Vind, J., Sjøholm, C., Lassen, S. F and DeMaria L. 2013. Degradation of phytate by the 6-Phytase from Hafnia alvei: a combined structural and solution study. Plos one. 31: 650-662.

Balota, E. L., Colozzi-Filho, A., Andrade, D. S and Dick, R. P. 2003. Microbial biomass in soils under different tillage and crop rotation systems. Biol. Fertil. Soils 38: 15-20.

Balota, E. L., Colozzi-Filho, A., Andrade, D. S and Dick, R. P. 2003. Microbial biomass in soils under different tillage and crop rotation systems. Biol. Fertil. Soils 38: 15-20.

Beare, M. H., Hu, S., Coleman, D. C and Hendrix, P. F. 1997. Influences of mycelial fungi on soil aggregation and organic matter storage in conventional and no-tillage soils. Appl. Soil. Ecol. 5: 211-219.

Benitez, E., Nogales, R., Campos, M and Ruano, F. 2006. Biochemical variability of olive orchard soils under different management systems. Appl. Soil. Ecol. 32: 221-231.

Bhaduri, D., Purakayastha, T. J., Singh, M and Wilson, B. R. 2017. Biological indicators of soil quality in a long-term rice-wheat system on the Indo-Gangetic plain: combined effect of tillagewater- nutrient management. Environ. Earth. Sci. 76: DOI 10.1007/s12665-017-6513-0.

Bini, D., Santos, C. A., Bernal, T., Andrade, G and Nogueira, M. A. 2014. Identifying indicators of C and $\mathrm{N}$ cycling in a clayey Ultisol under different tillage and uses in winter. Appl. Soil Ecol. 76: 95101.

Canarutto, S. M., Mazzoncini, A., Perna, S and Cervelli. 1995. The effect of reduction of inputs on phosphatase activity, organic carbon content and water stability index in a corn cultivated soil. Fresenius. Environ. Bull. 4: 291-296.

Chaudhury, J., Mandal, U. K., Sharma, K. L., Ghosh, H and Mandal, B. 2005. Assessing soil quality under long-term rice-based cropping system. Commun. Soil Sci. Plant Anal. 36: 11411161.

Chu, B., Zaid, F and Eivazi, F. 2016. Long-term effects of different cropping systems on selected enzyme activities. Commun. Soil Sci. Plant Anal. 47: 720-730.

De la Horra, A. M., Conti, M. E and Palma, R. M. 2003. $\beta$ - glucosidase and proteases activities as affected by long- term management practices in a Typic Argiudoll soil. Commun. Soil Sci. Plant Anal. 34: 2395- 2404.

Deng, S. P., and Tabatabai, M. A. 1996. Effect of tillage and residue management on enzyme activity in soil II. Glycosidases. Biol. Fertil. Soils 22: 208-213.

Dick, R. P., Rasmussen, P. E and Kerle, E. A. 1988. Influence of long-term residue management on soil enzyme activities in relation to soil chemical properties of a wheat-fallow system. Biol. Fertil. Soils 6: 159-164.

Dick, W. A., 1984. Influence of long-term tillage and crop rotation combinations on soil enzyme activities. Soil Sci. Soc. Am. J. 48: 569-574.

Dutta, M., Sardar, D., Pal, R and Kole, R. K. 2010. Effect of chlorpyrifos on microbial biomass and activities in tropical clay loam soil. Environ. Monit. Assess. 160: 385-391.

Eivazi, F., and Zakaria, A. 1993. $\beta$-Glucosidase activity in soils amended with sewage sludge. Agri. Ecosys. Environ. 43: 155-161.

Eivazi, F., Bayan, M. R and Schmidt, K. 2003. Selected soil enzyme activities in the historic Sanborn field as affected by long-term cropping systems. Commun. Soil Sci. Plant Anal. 3: 22592275.

Ekenler, M., and Tabatabai, M. A. 2003. $\beta$ Glucosaminidase activity of soils: Effect of cropping systems and its relationship to nitrogen mineralization. Biol. Fertil. Soils 36: 367-376.

Ekenler, M., and Tabatabai, M. A. 2004. Arylamidase and amidohydrolases in soils as affected by liming and tillage systems. Soil Till. Res. 77: 157-168.

Frankenberger, W. T., and Dick, W. A. 1983. Relationships between enzyme activities and microbial growth and activity indices in soil. Soil Sci. Soc. Am. J. 47: 945-951.

Gajda, A. M., Przewoka, B and Gawryjoek, K. 2013. Changes in soil quality associated with tillage system applied. Int. Agrophys 27: 133-141.

Hamido, S., and Kpomblekou. A. 2009. Cover crop and tillage effects on soil enzyme activities following tomato. Soil Till. Res. 105: 269-274.

Hayano, K., and Tubaki, K. 1985. Origin and properties of $\beta$-glucosidase activity of tomatofield soil. Soil Biol. Biochem. 17: 553-557.

Hebrien, S. A., and Neal, J. L. 1990. Soil pH and 
phosphatase activity. Commun. Soil Sci. Plant Anal. 21: 439-456.

Helgason, B. L., Walley, F. L and Germida, J. J. 2010. Long-term no-till management affects microbial biomass but not community composition in Canadian prairie agroecosytems. Soil Biol. Biochem. 42: 2192-2202.

Kandeler, E., and Bohm, K. E. 1996. Temporal dynamics of microbial biomass, xylanase activity, $\mathrm{N}$-mineralisation and potential nitrification in different tillage Systems. Appl. Soil Ecol. 4: 181191.

Kandeler, E., Tscherko, D and Spiegel, H. 1999. Long-term monitoring of microbial biomass, $\mathrm{N}$ mineralization and enzyme activities of a Chernozem under different tillage management. Biol. Fertil. Soils 28: 343-351.

Kladivko, E. J., 2001. Tillage Systems and Soil Ecology. Soil Till. Res. 61: 61-76.

Kumar, A., Somasundaram, J., Biswas, A. K., Sinha, N. K., Panda. A., Srivastava, L. K., Thakur, J and Mishra, V. N. 2017. Effect of conservation tillage on biological activity in soil and crop productivity under rainfed Vertisols of Central India. Int. J. Chem. Stud. 5: 98-104.

Kumawat, C., Sharma, V. K., Meena, M. C., Kumar. S., Barman, M., Chobhe, K. A and Yadav, R. K. 2017. Fluorescein diacetate activity as affected by residue retention and $\mathrm{P}$ fertilization in maize under maize-wheat cropping system. Int. J. Curr. Microbiol. App. Sci. 6: 2571-2577.

Lal, R., Follett, R. F and Kimble, J. 2003. Achieving soil carbon sequestration in the US: a challenge to the policy makers. Soil Sci. 168: 827-845.

Li, S., Zhang, S., Pu, Y., Li, T., Xu, X., Jia, Y., Deng, O and Gong, G. 2016. Dynamics of soil labile organic carbon fractions and C-cycle enzyme activities under straw mulch in Chengdu Plain. Soil Till. Res. 155: 289-297.

Ma, Y., Qin, H., Yin, C., Gao, W., Zhang, H., Sui, P., Chen, Y and Li, X. 2008. Dynamics of soil water content under different tillage systems in agro-pastural eco-zone. Front. Agric. China 2: 208-215.

Magnan, N., and Lynch, J. M. 1986. Water potential, growth and cellulolysis of fungi involved in decomposition of cereal residues. J. Gen. Microbiol. 132: 1181-1187.

Majchrzak, L., Sawinska, Z., Natywa, M., Skrzypczak, G and Głowicka-Wołoszyn, R. 2016. Impact of different tillage systems on soil dehydrogenase activity and spring wheat infection. J. Agr. Sci. Tec. 18: 1871-1881.
Mangalassery, S., Mooney, S. J., Sparkes, D. L., Fraser, W. T and Sjogersten, S. 2015. Impacts of zero tillage on soil enzyme activities, microbial characteristics and organic matter functional chemistry in temperate soils. Euro. J. Soil. Biol. 68: 9-17.

Martin, J. P., and Haider, K. 1980. A comparison of the use of phenolase and peroxide for the synthesis of model humic acid-type polymers. Soil. Sci. Soc. Am. J. 44: 983-988.

Mathew, R. P., Feng, Y., Githinji, L., Ramble, A and Kipling, S. 2012. Impact of no-tillage and conventional tillage systems on soil microbial communities. Appl. Environ. Soil Sci. doi:10.1155/2012/548620.

Matocha, C. J., Gerald, R. H and John, H. G. 2004. Nitrogen fertilization suppresses soil phenol oxidase enzyme activity in no-tillage systems. Soil Sci. 169(10): 708-714.

Meena, B. L., Saha, S., Kumar, N., Srivastva, A. K and Gupta, H. S. 2008. Changes in soil nutrient content and enzymatic activity under conventional and zero-tillage practices in an Indian sandy clay loam soil. Nutr. Cycl. Agroecosyst. 82: 273-281.

Nannipieri, P., Badalucco, L and Landi, L. 1994. Holistic approaches to study of populations, nutrient pools and fluxes: limits and future research needs. In: Beyond the Biomass: Compositional and Functional Analysis of Soil Microbial Communities, Ritz K, Dighton J and Giller K E. (Eds.) John Wiley \& Sons, Chichester, Pp 231-238.

Nannipieri, P., Greco, S and Ceccanti, B. 1990. Ecological significance of the biological activities in soil. In: Soil Biochemistry, vol 6, Bollog J M and Stotzky G. (Eds.) Marcel Dekker Inc, New York, Pp 293-55.

Neogi, S., Bhattacharyya, P., Roy, K. S., Panda, B, B., Nayak, A. K., Rao, K. S and Manna, M. C. 2014. Soil respiration, labile carbon pools and enzyme activities as affected by tillage practices in a tropical rice-maize-cowpea cropping system. Environ. Monit. Assess. 186: 4223-4236.

Parihar, C. M., Yadav, M. R., Jat, S. L., Singh, A. K., Kumar, B., Pradhan, S., Chakraborty, D., Jat, M. L., Jat, R. K., Saharawat, Y. S and Yadava, O. P. 2016. Long term effect of conservation agriculture in maize rotations on total organic carbon, physical and biological properties of a sandy loam soil in north-western Indo-Gangetic Plains. Soil Till. Res. 161: 116-128.

Passos, S. R., Reis Junior, F. B., Rumjanek, N. G., Mendes, I. C., Baptista, M. J and Xavier, G. R. 
2008. Atividade enzimática e perfil da comunidade bacteriana em solo submetido à solarização e biofumigação. Pesq. Agropec. Bras. 43: 879-885.

Quilchano, C., and Maranon, T. 2002 Dehydration activity in Mediterranean forest soils. Biol. Fertil. Soils 35: 102-107.

Raiesi, F., and Kabiri, V. 2016. Identification of soil quality indicators for assessing the effect of different tillage practices through a soil quality index in a semi-arid environment. Ecol. Indic. 71: 198-207.

Roldan, A., Caravaca, F., Hernandez, M. T., Garcia, C., Sánchez-Brito, C., Velasquez, $\mathrm{M}$ and Tiscareno, M. 2003. No-tillage, crop residue additions and legume cover cropping effects on soil quality characteristics under maize in Patzcuaro watershed (Mexico). Soil Till. Res. 72: 65-73.

Rotman, B., and Papermaster, B. W. 1966. Membrane properties of living mammalian cells as studied by enzymatic hydrolysis of fluorogenic esters. Proc. Nat. Acad. Sci. 55: 134-141.

Schnürer, J., and Rosswall, T. 1982. Fluorescein diacetate hydrolysis as a measure of total microbial activity in soil and litter. Appl. Environ. Microbiol. 43: 1256-1261.

Singh, A., and Ghoshal, N. 2013. Impact of herbicides and various soil amendments on soil enzymes activities in a tropical rainfed agroecosystem. Eur. J. Soil Biol. 54: 56-62.

Sinsabaugh, R. L., Moorhead, D, L and Linkins, A. E. 1994. The enzymatic basis of plant litter decomposition: emergence of an ecological process. Appl. Soil Ecol. 1: 97-111.

Spargo J, Cavigelli M, Mirsky S, Maul J and Meisinger J. 2011. Mineralizable soil nitrogen and labile soil organic matter in diverse long-term cropping systems. Nutr. Cycl. Agroecosyst. 90: 253-266.

Speir, T. W., and Ross, D. J. 1975. Effects of storage on the activities of protease, urease, phosphatase and sulphatase in three soils under pasture. $\mathrm{N} \mathrm{Z} \mathrm{J}$
Soil Sci. 18: 231-237.

Stevenson, F. J., 1994. Humus Chemistry: Genesis, Composition, Reactions. John-Wiley Interscience.

Tabatabai, M. A., 1994. Soil enzymes. In: Weaver R W, Angel J S and Bottomley P S. (Eds.) Methods of Soil Analysis, Part 2, Book Series 5, Soil Sci. Soc. Am. Madison, WI, Pp 775-33.

Tabatabai. M, A., 1982. Soil enzymes. In: Page A., Miller R H and Keeney D R. (Eds.) Methods of soil analysis, Agronomy 9, Am Soc Agron. Madison, USA, Pp 903-47.

Tarafdar, J. C., and Marschner, H. 1994. Phosphatase activity in the rhizosphere and hyposphere of VA mycorrhizal wheat supplied with inorganic and organic phosphorus. Soil Biol. Biochem. 26: 387-395.

Visser, S., and Parkinson, D. 1992. Soil biological criteria as indicators of soil quality, soil microorganisms. Am. J. Altern. Agric. 7: 33-37.

Waldrop, M. P., Balser, T. C and Firestone, M. K. 2000. Linking microbial community composition to function in a tropical soil. Soil Biol. Biochem. 32: 1837-1846.

Wong, K. K. Y., Tan, L. U. L and saddler. J. N. 1988. Multiplicity of bêta-1, 4-xylanase in microorganisms: functions and applications. Microbiol. Rev. 52: 305-307.

Yadav, B. K., and Tarafdar, J. C. 2004. Phytase activity in the rhizosphere of crops, trees and grasses under arid environment. J. Arid. Environ. 58: 285-293.

Zhang, J., Bo, G., Zhang, Z., Kong, F., Wang, Y and Shen, G. 2016. Effects of straw incorporation on soil nutrients, enzymes, and aggregate stability in tobacco fields of China. Sustainability. 8: 710721.

Zhao, S., Li, K., Zhou, W., Qiu, S., Huang, S and He. P. 2016. Changes in soil microbial community, enzyme activities and organic matter fractions under long-term straw return in northcentral China. Agric. Ecosyst. Environ. 216: 8288.

\section{How to cite this article:}

Rituparna Saikia and Sandeep Sharma. 2017. Soil Enzyme Activity as Affected by Tillage and Residue Management Practices under Diverse Cropping Systems. Int.J.Curr.Microbiol.App.Sci. 6(10): 1211-1218. doi: https://doi.org/10.20546/ijcmas.2017.610.146 